\title{
Bilateral Internuclear Ophthalmoplegia in Myasthenia Graves
}

\section{Myastenia Graviste Bilateral İnternükleer Oftalmopleji}

\author{
(1) Gülhan Sarıçam, (1) Ebru Bilge Dirik, (๖ Şener Akyol, (1) Ömer Anlar \\ Ankara Ataturk Training and Research Hospital, Clinic of Neurology, Ankara, Turkey
}

Keywords: Myasthenia gravis, internuclear ophthalmoplegia, medial longitudinal fasiculus

Anahtar Kelimeler: Myastenia gravis, internükleer oftalmopleji, mediyal longitudinal fasikülüs

\section{Dear Editor,}

Myasthenia gravis (MG) is an autoimmune disorder, which affects the oculobulbar muscles, and is characterized by muscle weakness that worsens with exercise. Mostly, postsynaptic nicotinic acetylcholine receptors (AChR) are targeted in MG (1).

Some muscles are more affected in MG, mostly eye lids and ocular muscles, and less frequently, muscles of the face, jaw, throat, and neck are the first affected muscles. More specifically, in half of all patients, weakness of the levator palpebra and extraocular muscles is the first symptom of MG, and later, these muscles are affected in more than $90 \%$ of patients (2). Ptosis can be unilateral or bilateral, but it is usually asymmetric if bilateral. Involvement of extraocular muscles is usually bilateral but does not suggest a specific pattern such as an involvement of one nerve or a pattern such as internuclear ophthalmoplegia (INO) or conjugate gaze palsy, which are seen in disorders of the brainstem. However, rarely, such presentations may be observed in MG (2).

A 33-year-old female was admitted to neurology clinic with general weakness, diplopia, and vertigo lasting for 1 week. She used to take long morning walks but she gradually began to have an increased need to rest and walk shorter distances. Due to horizontal diplopia, she had vertigo and nausea. She felt well in the mornings but worsened with physical exercise.

There were no features in her medical history and she was not taking any regular medication. Physical examination was normal. In the neurologic examination, she was conscious, cooperated, and was oriented. Her pupils were isochoric and bilateral direct and indirect responses to light were positive. She had no ptosis. She had bilateral INO (Figure 1A, 1B). The fundus examination was normal. The eye exhausting test was negative. Her pharyngeal reflex was positive and she could swallow. There was no facial asymmetry. Deep tendon reflexes were normal. There was no muscle weakness in any of the extremities. There was no ataxia or pathologic reflexes.

Total blood count, biochemical test, complete urinalysis test, sedimentation rate, C-reactive protein, posteroanterior chest radiography, electrocardiography, thyroid function tests, serologic tests, and markers of vasculitis were within normal limits. Cranial magnetic resonance imaging (MRI) was performed to exclude intracranial pathologies because the patient had bilateral INO, and MRI was normal. Antibodies against AChR in the blood were $5.15 \mathrm{nmol} / \mathrm{L}(\mathrm{n}:<0.25)$. Repetitive stimulation performed to the nasal muscle for the diagnosis of MG revealed normal findings. Single-fiber electromyography (EMG) showed increased jitter. Thorax computed tomography showed a thymoma.

Pyridostigmine bromide $60 \mathrm{mg} / \mathrm{d}$ was initiated and the dosage was increased up to $360 \mathrm{mg} / \mathrm{d}$. Methylprednisolone $80 \mathrm{mg} / \mathrm{d}$ was initiated at the same time. After the patient was stabilized, the methylprednisolone dose was reduced gradually and stopped. The bilateral INO completely improved and her general weakness partially improved. Thymectomy was planned and she was discharged (Figure 1C, 2A, 2B).

Bulbar, extremity, and respiratory muscles are affected in generalized MG, whereas levator palpebra and orbicularis oculi

Address for Correspondence/Yazışma Adresi: Gülhan Sarıçam MD, Ankara Ataturk Training and Research Hospital, Clinic of Neurology, Ankara, Turkey Phone: +90 5056298466 E-mail: gulhansar01@hotmail.com ORCID ID: orcid.org/0000-0002-9032-6877

Received/Geliş Tarihi: 28.03.2016 Accepted/Kabul Tarihi: 02.08.2017

${ }^{\oplus}$ Copyright 2018 by Turkish Neurological Society

Turkish Journal of Neurology published by Galenos Publishing House. 

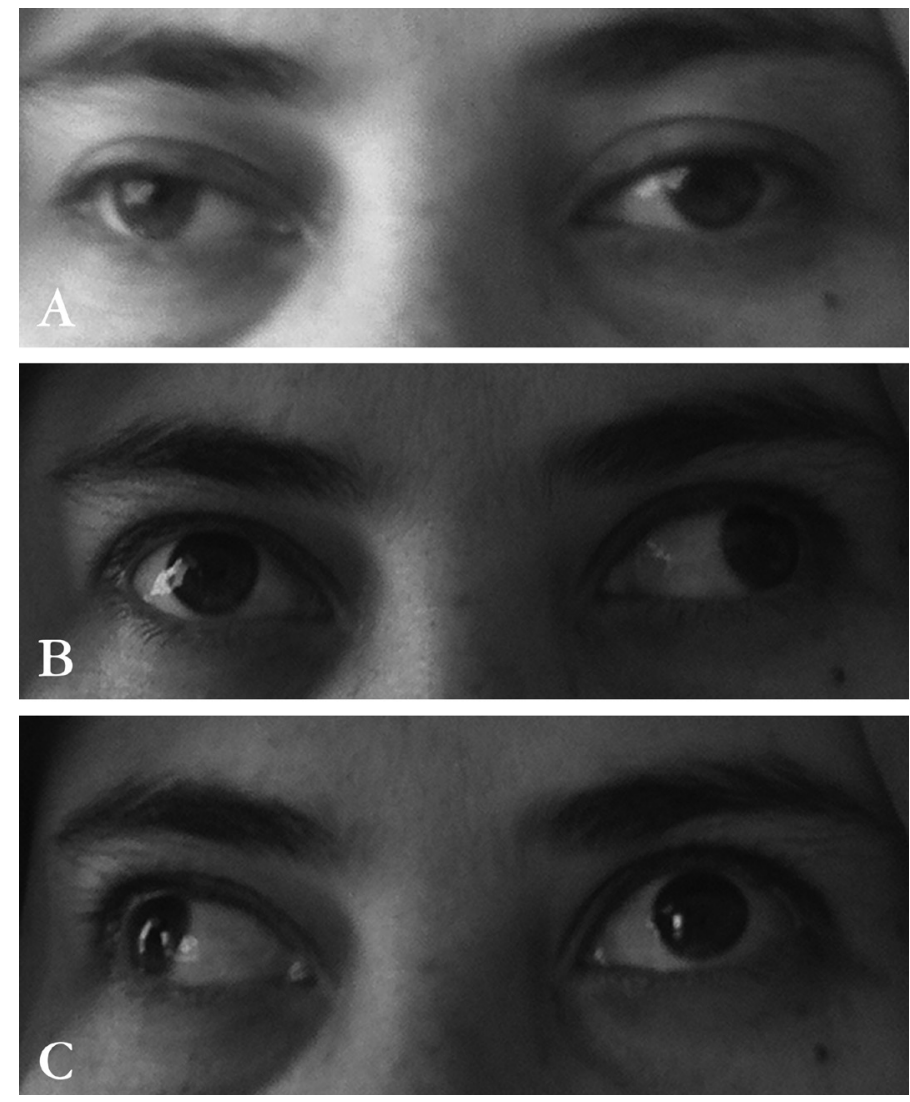

Figure 1. Eye movements of the patient with bilateral internuclear ophthalmoplegia: A) Neutral position, B) Looking left, C) Looking right
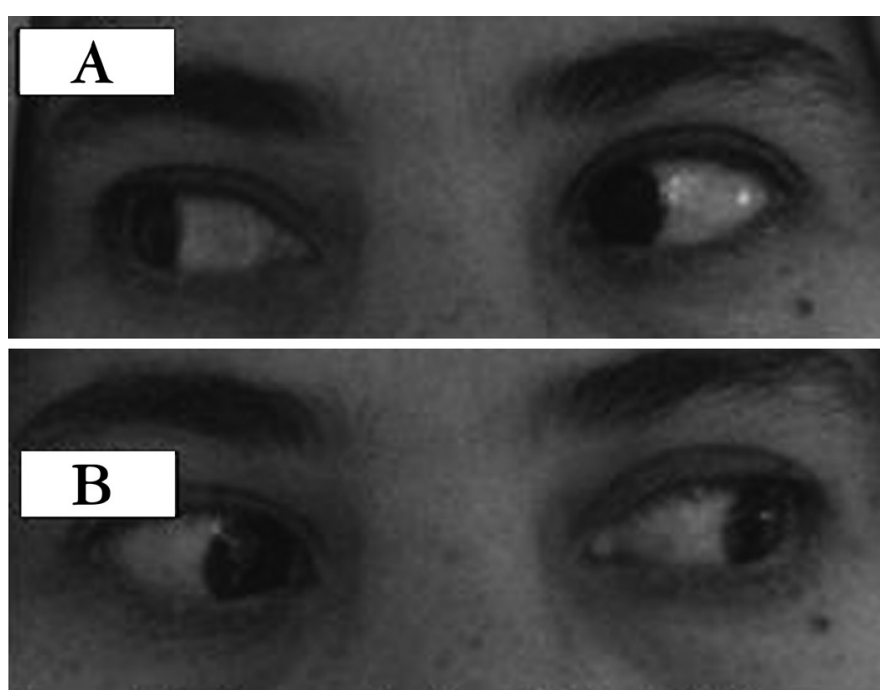

Figure 2. Eye movements of the patient after the treatment: A) Looking right, B) Looking left muscles are affected in ocular MG. Ptosis and diplopia are the first symptoms in more than $50 \%$ of patients and $50-80 \%$ of those patients develop generalized MG later (3). Ocular MG evolves to generalized MG in $90 \%$ of patients in 2 years (4).

Extraocular muscle weakness can mimic INO in MG but there is no central nervous system involvement; therefore, it is called pseudo-INO. Intermittent blocks in extraocular neuromuscular transmission cause muscle weakness in MG. Although the pathogenesis of weakness of adduction in MG differs from INO, the abduction nystagmus in INO and pseudo-INO share the same pathogenetic mechanism. Pseudo-INO can be seen in GuillainBarre syndrome (GBS) or in Miller-Fisher syndrome, a GBS variant.

Studies on procedures such as orbicularis reflex tests to distinguish INO and pseudo-INO are still ongoing (5).

Our patient was admitted with bilateral pseudo-INO. Multiple sclerosis, Graves' ophthalmopathy, Miller-Fisher syndrome, mitochondrial diseases, oculopharyngeal muscular dystrophy, vascular causes, and tumors were considered in the differential diagnosis. Medical history findings, increased jitter in single fiber EMG, increased AChR antibodies, and good response to cholinesterase inhibitors suggested the diagnosis of MG. Also, existence of thymoma supported the diagnosis of MG.

As a result, MG can present with various clinic pictures. INO should be kept in mind in MG besides ptosis and diplopia and patients with INO should also be checked for MG.

\section{Ethics}

Informed Consent: Informed consent not used.

Peer-review: Internally peer-reviewed.

\section{Authorship Contributions}

Concept: G.S., Design: E.B.D., Data Collection or Processing: Ş.A., Analysis or Interpretation: Ö.A., Literature Search: G.S., Writing: G.S.

Conflict of Interest: Authors declared no conflict of interest.

Financial Disclosure: The authors did not receive financial aid or funding.

\section{References}

1. Öge AE, Baykan B. Kas ve Nöromuskuler Kavşak Hastalıkları. In: Serdaroğlu Oflazer P, Deymeer F (eds). İstanbul Tip Fakültesi Temel ve Klinik Bilimler Nöroloji Ders Kitapları. 2nd ed. İstanbul: 2011:759-669.

2. Nair AG, Patil-Chhablani P, Venkatramani DV, Gandhi RA. Ocular myasthenia gravis: a review. Indian J Ophthalmol 2014;62:985-991.

3. Antonio-Santos AA, Eggenberger ER. Medical treatment options for ocular myasthenia gravis. Curr Opin Ophthalmol 2008;19:468-478.

4. Oosterhuis HJ. Observations of the natural history of myasthenia gravis and the effect of thymectomy. Ann N Y Acad Sci 1981;377:678-690.

5. Nijsse B, Bettink MW, Neuteboom RF. Pseudointernuclear ophthalmoplegia as a presenting feature of ocular myasthenia gravis. BMJ Case Rep 2014;2014;bcr2013203234. 